\title{
PEMETAAN PENDIDIKAN KEAGAMAAN
}

\author{
Oleh: Abd. Kadir M.
}

\begin{abstract}
This writing is a research conclusion, that was conducted at several places. They are Manado, Ternate, Jayapura, Makassar, Ambon, Palu, Samarinda, Mamuju, and Kendari. Data was collected using interview and questioner. Data was analyzed using qualitative description.

This study indicates that (1) local government and society support to Islamic school is very good; (2) organization of school is conducted by participative; (3) This schools output is very good.
\end{abstract}

Keyword: Islamic School.

\section{A. Pendahuluan}

r Tulisan ini merupakan saduran dari hasil penelitian tentang pemetaan pendidikan keagamaan yang dilakukan di beberapa provinsi di Indonesia

JL Timur yang meliputi Sulawesi Utara, Maluku Utara, Papua, Sulawesi Selatan, Maluku, Gorontalo, Sulawesi Tengah, Kalimantan Timur, Sulawesi Barat, dan Sulawesi Tenggara.

Tulisan ini dilatarbelakangi oleh pemikiran bahwa pembangunan manusia Indonesia seutuhnya merupakan cita-cita ideal yang menjadi basis historis keberadaan Departemen Agama dengan secara konsisten menjamin teraktualisasinya Pancasila, terutama pesan moral yang tertuang di dalam sila pertama; Ketuhanan Yang Maha Esa, serta aturan pelaksanaannya. Hal-hal yang berhubungan langsung dengan Departemen Agama adalah tentang peningkatan kualitas kehidupan beragama, penciptaan tata pemerintahan yang bersih dan berwibawa serta peningkatan akses masyarakat terhadap pendidikan yang berkualitas.

Untuk menjalankan tugas yang diamanahkan pemerintah, Departemen Agama telah menyusun Rencana Strategis (Renstra) 2005-2009, yang di 


\section{Abd. Kadir M.}

dalamnya antara lain memuat visi dan misi Departemen Agama yang ditetapkan melalui Keputusan Menteri Agama Nomor 8 Tahun 2006, yaitu: terwujudnya masyarakat Indonesia yang taat beragama, maju, sejahtera, dan cerdas serta saling menghormati antara sesama pemeluk agama dalam kehidupan bermasyarakat, berbangsa dan bernegara dalam wadah Negara Kesatuan Republik Indonesia.

Selanjutnya, misi Departemen Agama diformulasikan sebagai berikut: pertama, meningkatkan kualitas bimbingan, pemahaman, pengalaman dan pelayanan kehidupan beragama. Kedua, meningkatkan penghayatan moral dan etika keagamaan. Ketiga, meningkatkan kualitas pendidikan umat beragama. Keempat, meningkatkan kualitas penyelenggaraan haji. Kelima, memberdayakan umat beragama dan lembaga keagamaan. Keenam, memperkokoh kerukunan umat beragama, dan ketujuh, mengembangkan keselarasan pemahaman keagamaan dengan wawasan kebangsaan Indonesia.

Departemen Agama sesuai tugas pokoknya telah melaksanakan pembinaan dan pengembangan kualitas kehidupan beragama. Mulai dari penjaminan kebebasan beragama bagi segenap warga bangsa, pemberian pelayanan keagamaan, hingga pembangunan infra struktur bagi umat beragama. Bahkan Departemen Agama hingga saat ini secara signifikan berkonstribusi besar dalam memproteksi, menjaga serta memobilisasi dan menjadi motivator pembangunan di bidang agama.

Sebagai pelaksana teknik, Badan Litbang dan Diklat Dep. Agama dengan visi "terwujudnya kebijakan pembangunan agama berbasis hasil riset dan tersedianya sumberdaya manusia Departemen Agama yang berkualitas", mendesain riset dalam rangka formulasi pemetaan pendidikan keagamaan di Indonesia, khususnya pada zona Indonesia Timur yang menjadi wilayah kerja Balai Penelitian dan Pengembangan Agama Makassar. Riset ini urgen ketika mengingat sorotan publik terhadap berbagai aspek yang masih mengalami kelemahan di lingkungan Departemen Agama, diataranya: (1) masih rendahnya kualitas pemahaman, penghayatan, dan pengamalan nilai-nilai yang diajarkan agama pada tataran masyarakat, belum optimalnya pelayanan kehidupan beragama; dan masih menggejalanya ekslusifisme dan komunalisme di kalangan penganut agama, baik dalam hubungan internal maupun hubungan antar umat beragama, serta kehidupan yang harmonis pada ranah akar rumput belum sepenuhnya terwujud antar lain sebagai akses dari ketegangan sosial yang acapkali bermuara pada konflik, (2) kehidupan beragama pada sebagian 
masyarakat bam pada tataran simbolik, (3) pelayanan keagamaan yang belum optimal, (4) rendahnya mutu pendidikan di lembaga pendidikan Islam yang berimplikasi pada rendahnya kualitas out put lembaga tersebut, (5) minimnya infrastruktur yang masih membebani tugas-tugas pegawai dalam upaya menigkatkan kenerja.

Merujuk signifikansi peranan agama dalam membangun manusia Indonesia seutuhnya, baik spiritual maupun material, diperlukan dukungan kebijakan, sumber daya, informasi, sekaligus infrastruktur untuk mendukung program pembangunan di bidang agama khususnya pada aspek pendidikan. Dalam rangka akselerasi pencapaian target strategi di atas, dibutuhkan informasi yang akurat serta faktual. Oleh karena itu, untuk mendapatkan data dan informasi tersebut, urgen untuk dilakukan identifikasi serta inventarisasi masalah pendidikan keagamaan melalui kajian kepustakaan dan dokumen, serta wawaneara langsung yang dilakukan secara konprehensif.

\section{Ruang Lingkup Penelitian}

Pendidikan sebagai suatu sistem memiliki lima komponen yang satu sama lain salingterkait, yaitu: konteks, input, proses, output, dan outcome.

Konteks adalah ekternalitas atau faktor luar yang memberikan conditioning atau peluang bagi keadaan lembaga pendidikan dan pengembangan aktivitasnya. Ini dapat berbentuk lingkungan alam fisik dan lingkungan sosial ekonomi dan budaya, tetapi juga dapat berupa demand dan support (permintaan dan dukungan) dari masyarakat dan pemerintah.

In put adalah segala "sesuatu" yang harus tersedia dan siap potensi karena dibutuhkan untuk berlangsungnya proses. Sesuatu yang dimaksud itu dapat berwujud benda/barang dan institusi, dapat berbentuk perangkat-perangkat lunak, serta berbentuk harapan-harapan sebagai pemandu bagi berlangsungnya proses

Proses adalah berubahnya sesuatu menjadi sesuatu yang lain. Dalam suatu lembaga pendidikan, proses itu dapat terdiri dari antara lain proses pengambilan keputusan, proses pengelolaan kelembagaan, pengelolaan program, proses belajar mengajar, proses evaluasi sekolah, proses akuntabilitas. Inti proses adalah konsisteninkonsistensi antara rancangan atau desain semula dengan implementasinya.

Out put adalah hasil nyata dari pelaksanaan kegiatan, khususnya kegitan proses belajar mengajar baik internalkulrikuler maupun eksternalkuikuler, nilai ebta, ebtanas, UAN, dan perangkat nonakademik misalnya kejujuran, Imtaq, 
Abd. Kadir $M$.

kedisiplinan, prestasi olahraga, dan kesenian, serta kerajinan. Inti out put ini adalah sejauhmana "hasil nyata atau sesaat" sesuai dengan "hasil sasaran yang diharapkan"

Out come adalah hasiljangka panjang atau manfaat sekolahjangka panjang, baik berupa dampak individu maupun merupa dampak sosial misalnya pendidikan lebih lanjut, pekerjaan, penghasilan, pengembangan karir, dan kesempatan berkembang.

\section{B. Temuan Penelitian}

\section{Dukungan pemerintah}

Keberadaan pendidikan agama Islam mendapat respon pemerintah. dalam penemuan.di lapangan bahwa di beberapa daerah yang mayoritas penganutnya beragama Kristen seperti Manado, Ambon, dan Jayapura, namun lembaga pendidikan agama masih tetap mendapat perhatian.

Di Ambon penganut agama yang mayoritas, adalah Kristen sebanyak $50,18 \%$, namun jumlah lembaga pendidikan Islam yang tersedia mulai dari tingkatan ibtidaiyah sampai perguruan tinggi baik swasta maupun negeri. Dari data yang ada lembaga pendidikan Islam yang terdapat di Ambon adalah Madrasah Ibtidaiyah (MI) 9 (sembilan) buah, Madrasah Tsanawiyah (MTS) 9 (sembilan) buah, Madrasah Aliyah (MA) 5'(lima) buah, dan Perguruan Tinggi Agama Islam (PTAI) 1(satu) buah.

Sedangkan di Sulawesi Utara tampaknya memilki kecenderuangan yang sama dengan Ambon, jumlah pengenut agama yang mayoritas adalah penganut agama Kristen sebanyak 63,51\%, namun lembaga-lembaga pendidikan agama Islam-pun tersedia mulai dari tingkat Madrasah Ibtidaiyah samapai Perguruan Tinggi Agama Islam, jumlah Madrasah Ibtidaiyah 41 buah, Madrasah Tsanawiyah 39 buah, Madrasah Aliyah 12 buah, dan Perguruan Tinggi Agama Islam 1 (satu) buah (STAPN) Manado.

Selain itu dukungan pemerintah terhadap lembaga pendidikan Islam didirikan beberapa sekolah Islam negeri mulai dari Madrasah Ibtidaiyah sampai Perguruan Tinggi Negeri.

\section{Dukungan Masyarakat}

Perhatian masyarakat terhadap pendidikan agama Islam cukup tinggi, hal ini dapat dibuktikan pada kuantitas lembaga pendidikan agama Islam yang 
dikelolah oleh masyarakat sangat banyakjumlahnya. Hal ini dapat dibuktikan dengan data yang diperoleh di lapangan.

Misalnya data di Sulawesi Utara, Madrasah Ibtidaiyah Swasta (MIS) yang dikelolah oleh masyarakat sebanyak 75,61\%, Madrasah Tsanawiyah yang dikelolah oleh masyarakat $82 \%$, Madrasah Aliyah $83 \%$ dan selebihnya dikelolah oleh pemerintah. Di Kota Kendari MIS yang dikelolah oleh masyarakat $75 \%$, Madrasah Tsanawiyah 70\%, Madrasah Aliyah 75\%, dan selebihnya dikelolah oleh pemerintah.

In put

\section{Institusi lembaga pendidikan Islam swasta dan negeri}

Dari data semua lokasi penelitian ketersediaan lembaga pendidikan agama Islam pada semuajenjang mulai jenjang paling rendah yaitu TK (Raudatul Atfal) sampai pada Perguruan Tinggi, bahkan pada beberapa lokasi penelitian ada kecenderuangan lembaga pendidikan agama Islam itu mengalami peningkatan yang signifikan. Misalnya di Kota Samarindajumlah RA sebanyak 6 (enam) buah, MI sebanyak 16 buah, MTS sebanyak 26 buah, dan MA sebanyak 11 buah, dan Perguruan Tinggi Agama Islam sebanyak 2 (dua) buah. Di Gorontalo jumlah MI sebanyak 57 buah, Madrasah Tsanawiyah 54 buah, MA sebanyak 21 buah, dan Perguruan Tinggi Agama Islam 1 (satu) buah.

\section{Harapan-visi dan misi}

Salah satu in put dari lembaga pendidikan Islam adalah pencapaian harapan. Pencapaian harapan itu dilandasi oleh visi dan misi yang telah dibuat oleh masingmasing lembaga pendidikan agama Islam. Pada semua lembaga pendidikan Islam yang telah ditekti semua mempunyai visi dan misi yang hampir sama yang merupakan patokan dalam menyusun program kerja suatu kegiatan yang akan dilaksanakan. Secara garis besar yang termuat dari visi dari masing-masing lembaga pendidikan adalah:

a. Sumber daya yang berkualitas;

b. penguasaan ilmu pengetahuan dan ilmu umum;

c. persiapan memasuki perguruan dan dunia kerja; dan

d. lembaga pendidikan agama yang unggul dan kompetitif.

Untuk mencapai visi itu maka disusun misi dengan menyesuaikan kondisi dan kemampuan yang dimiliki oleh masing-masing lembaga pendidikan Islam adalah: 
b. Peningkatan SDM;

c. pencapaian tujuan pendidikan;

d. peningkatan kualitas lembaga pendidikan; dan

e. upaya pencapaian alumni yang handal dan profesional.

\section{Sumber daya manusia}

In put yang lain dalam lembaga pendidikan agama adalah sumber daya manusia yang terdiri dari tenaga pengajar dan tenaga administrasi sekolah, hampir semua di lokasi penelitian menunjukkan bahwa tingkat profesional isme tenaga pengajar cukup tinggi, hal ini dapat ditunjukkan pada pendidikan terakhir pada tenanga pengajar tersebut. Secara umum mayoritas mereka adalah keluaran PerguruanTinggi (SI) demikian halnya dengan disiplin ilmuyang merekaajarkan. Seperti pada data yang telah ditemukan di lapangan.

Misalnya di Kota Samarinda yang menjadi sampel adalah MAN 2 Samarinda, PesantrenNabil Husein dan SMK Istiqamah Muhammadiyah. MAN 2 Samarinda terdapat sebanyak 55 orang dengan rincian S2 8 (delapan) orang, S1 42 orang, dan Dili sebanyak 5 (lima) orang, sedangkan Pesantren Nabil Husein S2 2 (dua) orang, SI 21 orang, dan SMA 4 (empat) orang. SMK Istiqamah Muhammadiyahjumlah gurunya 45 orang dengan rincian S2 2 (dua) orang, SI 41 orang, dan Dili 2 (dua) orang..

Di Sulawesi Barat yang menjadi sampel adalah MAN Mamaju, dan Pesantren DDI Tappalang. MAN Mamuju terdapat 36 orang tenaga pengajar kesemuanya alumni S1, sedangkan Pondok Pesantren DDI Tappalang terdapat 35 orang tenaga pengajar yang berpendidikan SI dari berbagai disiplin ilmu agama dan umum. Di Jayapura yang menjadi sampel Madrasah Aliyah DDI Jayapura dari 14 guru kesemuanya berpendidikan S1 baik dari perguruan tinggi negeri maupun swasta.

\section{Sarana lembaga pendidikan}

Sarana pendidikan merupakan aspek terpenting dalam kelangsungan proses belajar mengajar pada lembaga pendidikan, dukungan sarana dan prasarana yang lengkap akan berpengaruh pada pencapaian tujuan pendidikan dalam suatu lembaga pendidikan. Secara umum disemua lokasi penelitian kelengkapan sarana dan prasarana masih sangat relatif antara lembaga-lembaga pendidikan yang telah diteliti seperti MAN Model Manado sarana dan prasarananya cukup memadai dilengkapi dengan ketersediaan ruang belajar sebanyak 18 kelas, 1 
(satu) buah gedung perkantoran dengan luas $460 \mathrm{M} 2$, luas tanah kampus 10,073 M2, Laboratorium dan perpustakaan $596 \mathrm{M} 2$, ruang keterampilan tata busana 150 M2, keterampilan tata boga 150 M2, serta ruangan keterampilan muebel 210 M2, madrasah ini ditunjang oleh gedung PSPB, asrama, masjid, rumah dinas, dan lapangan olahraga. Kesemua fasilitas yang dimiliki MAN Model Manado hampir sama dengan fasilitas yang dimiliki oleh MAN Model Samarinda.

Sedangkan lembaga pendidikan yang belum memadai prasarana dan sarananya seperti pada Pondok Pesantren DDI Tappalang yang mempunyai fasilitas asrama 1 (satu) unit putra dan putri, ruang belajar 3 (tiga) kelas, tidak memiliki laboratorium, perpustakaan terbatas, alat mobiler seperti bangku dan kursi 215 buah dan yang rusak 95 buah.

\section{Out put}

Hasil penelitian yang telah dilakukan secara keseluruhan out put pada lembaga pendidikan Islam, ditinjau darijumlah siswa yang lulus di atas $90 \%$. Data yang diperoleh dari MAN Mamuju tingkat kelulusan siswa mencapai $100 \%$ pada tahun 2005-2006, Pondok Pesantren DDI Tappalang 91,3\%. Di Kota Kendari.tingkat kelulusan siswa pada MAN 1 100\%, sedangakan SMU Swasta Muhammadiyah $93 \%$. Berbeda halnya dengan Kota Samarinda, tingkat kelulusan siswa pada MAN Model Samarinda 99,6\%, Pesantren Nabil Husein 99\%, dan SMK Istiqamah Muhammadiyah 4 Samarinda $100 \%$.

Proses

If

\section{Proses pengambilan keputusan dan pengelolaan lembaga}

Salah satu proses yang menentukan keberhasilan pendidikan adalah proses pengambilan kebijakan. Secara umum pimpinan lembaga-lembaga pendidikan melakukan pengambilan keputusan melalui 2 (dua) macam proses yaitu proses terpusat pada pimpinan dan proses partisipatif yang melibatkan pihak-pihak yang terkait.

Seperti proses hirarki pengambilan keputusan yang dituangkan dalam subuah kebij akan senantiasa menganut metode' 'button up" yakni senantiasa menggali gagasan dari kalangan guru, pengawai administrasi, masyarakat, dan stake holder lainnya, kemudian gagasan tersebut selanjutnya dipelajari dan akan singkronkan dengan aturan dan mekanisme yang ada. Demikian juga proses pelaksanaan manajemen sekolah dan belajar mengajar, senantiasa dilakukan evaluasi yang akan mempelajari kendala ataupun potensi yang dimiliki. Hal ini tercermin melalui rapat evalusi rutin terhadap pola manajemen yang berjalan utamanya proses belajar mengajar. 


\section{Abd. Kadir $M$.}

\section{Proses pengelolaan lembaga}

Pada proses pengelolaan lembaga pihak madrasah (kepala sekolah) tidak dilibatkan secara langsung, akan proses pengelolaan lembaga ditangani langsung oleh pengelola yayasan, jika lembaga-lembaga pendidikan di bawah naungan yayasan. Sedangkan pengelolaan lembaga pendidikan negeri adalah dominan menggunakan pengelolaan partisipatif yakni pengelolaan lembaga komite sekolah dalam hal ini memberi masukan kepada sekolah untuk peningkatan kualitas lembaga dan menyiapkan kebutuhan untuk kegiatan berupa dana.

\section{Proses pengelolaan program}

Proses pengelolaan program dilakukan secara partisifatif antara pengambil kebijakan (kepala sekolah) berserta bawahannya (guru) dalam mengelola program khususnya proses belajar mengajar, pengelolaan program dilakukan secara buttom-up.

\section{Proses belajar-mengajar}

Pelaksanaan proses belajar mengajar yang dilakukan di lembaga pendidikan dominan bersifat kooperatif artinya kegiatan itu tidak terpusat pada guru atau siswa semata tapi ada hubungan timbal balik antara guru dan siswa. Di samping itu dalam proses belajar menjagar nampaknya Komite Sekolah juga terlibat, khusus mengenai program belajar tambahan seperti kegiatan keagamaan, pelatihan dakwah dan program Try Out Madrasah. Komite Sekolah dalam hal ini senantiasa menyiapkan dana untuk penyelenggaraan kegiatan demi peningkatan mutu kelulusan (alumni).

\section{Proses evaluasi sekolah}

Sistem evaluasi yang dilakukan pada lembaga pendidikan Islam adalah konsisten pada desain yakni adanya kerjasama dengan guru-guru bidang studi yang mengajar di madrasah. Proses evaluasi harian dilaksanakan oleh guru, evaluasi semester dilakukan oleh sekolah sedangkan evaluasi nasional dilakukan secara terpusat. Akan tetapi dalam hal ini sekolah punya kegiatan lain seperti pelaksanaan ujian akhir nasional pihak madrasah melakukan try out dengan menambahjam pelajaran menjadi $18 \mathrm{X}$ pertemuan demi memperoleh kelulusan dan produktivitas yang mencapai nilai rata-rata yang standar.

\section{Proses akuntabilitas}

Preses pertanggungjawaban lembaga pendidikan baik kepada pemerintah maupun masyarakat pada madrasah-madrasah berjalan dengan lancar. Pihak 
madrasah senantiasa melakukan koordinasi kepada pihak pemerintah dan melakukan kerja sama yang baik yakni mengikuti sistem yang telah ada. Demikian pula pertanggungjawaban terhadap masyarakat (orang tua) santri madrasah dalam hal ini memberikan pembinaan dan didikan kepada mereka sebaik mungkin khususnya dalam hal pelaksanaan uj ian dilakuka berbagai upaya dalam rangka pencapain mutu kualitas luarannya (telorannya) sehingga mampu bersaing dengan sekolah unggulan lainnya dan dapat diterima diberbagai Perguruan Tinggi baik negeri maupun swasta.

\section{Out Come}

Indikator out come lembaga pendidikan Islam dapat diukur padajumlah keluaran yang terserap di perguruan tinggi negeri maupun swasta yang telah mampu melahirkan dan mencetak manusia-manusia yang berdaya guna di masyarakat yang dibuktikan luaran lembaga pendidikan Islam telah banyak menempati posisi penting dalam berbagai sektor baik pemerintah maupun swasta misalnya di MAN Mamuju 4 (empat) orang yang lulus pada perguruan tinggi negeri dari 110 siswa.

\section{Penutup}

\section{Kesimpulan}

1. Dukungan pemerintah dan masyarakat terhadap lembaga pendidikan agama Islam cukup tinggi, dapat dilihat pada kebijakan pemerintah tentang fleksibilitas pendirian lembaga-lembaga pendidikan Islam meskipun di wilayah-wilayah yang mayoritas dihuni oleh penganut agama nonislam. Sedangkan dukungan masyarakat terhadap lembaga pendidkan Islam berupa keterlibatan masyarat dalam mengelolah dan membina lembaga pendidikan agama Islam (swasta)

2. Lembaga Pendidikan Agama Islam cukup tersedia dari semuajenjang dan jenis pendidikan. Ketersediaan pendidikan dari jenjang pendidikan meliputi Raudatul Atfal, Madrasah Ibtidaiyah, Madrasah Tsanawiyah, Madrasah Aliyah, dan Perguruan Tinggi Islam. Sedangkan dari jenis pendidikan ketersediaan lembaga pendidikan meliputi sekolah umum yang bercirikan Islam seperti madrasah dan pesantren.

3. Proses pengelolaan lembaga pendidikan Islam dilakukan secara partisipatif (semua stake holder terlibat). Masyarakat terlibat sebagai pengelola dalam komite sekolah, pemerintah terlibat sebagai pendukung kebijakan aturan dan pendanaan, pimpinan sekolah terlibat dalam mengelolah program, dan guru terlibat dalam proses belajar mengajar. 
4. Out put lembaga pendidikan Islam cukup tinggi hal ini dapat dilihat pada presentase keluaran siswa lembaga pendidikan agama Islam mencapai di atas $90 \%$. Demikian halnya nilai rata-rata hasil ujian nasional siswa lembaga pendidikan Islam mendekati nilai srtandar yang telah ditentukan oleh ditentukan oleh pemerintah.

5. Keterserapan keluaran lembaga pendidikan di perguruan tinggi dan lapangan pekerjaan sangat relatif.

\section{Rekomendasi}

1. Perlu peningkatan keterlibatan pemerintah dalam pembinaan lembaga pendidikan Islam yang selama ini masih banyak dilaksanakan oleh masyarakat terutama dalam mengatasi operasionalisasi lembaga pendidikan yang dirasakan semakin mahal.

2. Perlunya keseimbangan antara peningkatan lembaga pendidikan agama Islam dari segi kuantitas dengan peningkatan dari segi kualitas sehingga dapat menghasilkan out put dan out come yang lebih berkualitas.

\section{DAFTAR PUSTAKA}

Killen, Roy. 1998. Effective Teaching Strategies: Lesson form Research and Practice. Social Science Press, Australia.

Makmun, Abin Syamsuddin. 1996. Pskilogi Kependidikan. Bandung: PT. Remaja Rosdakarya, cetakan pertama.

Mar'at. 1981. Sikap Manusia Perubahan sertaPengukurannya (Jakarta: Ghalia Indonesia, cetakan pertama.

Moleong, Lexy. 1989. Metodology Penelitian Kualitatif, Remadja Karya, Bandung.

Piaget, J. 1971. Psychology andEpistemologi. The Viking Press: New York.

Rahim, Husni. 2001. Arab Baru Pendidikan Islam di Indonesia. PT. Logos Wacana Ilmu, Ciputat.

- 2003. Madrasah dalam Politik Pendidikan di Indonesia. Pt. Logos Wacana Ilmu, Ciputat.

Sanjaya, Wina. 2006. StrategiPembelajaran BerorientasiStandar Proses Pendidikan. Kencana Prenada Media, Jakarta.

Sukardi. 2004. Metodologi Penelitian Pendidikan; Kompetensi dan Praktiknya. Bumi Aksara, Jakarta.. 